\title{
Typhoon Haikui induced sea surface temperature cooling and rainfall influence over Zhejiang coastal waters
}

\author{
M. V. SUBRAHMANYAM ${ }^{1}$, Yu SHENGYAN ${ }^{1}$ and P.V.S. RAJU ${ }^{2 *}$ \\ ${ }^{1}$ School of Marine science and Technology, Zhejiang Ocean University, Zhoushan, 316022, China. \\ ${ }^{2}$ Centre for Ocean Atmospheric Science \& Technology (COAST), Amity University Rajasthan, Jaipur 303002, Rajasthan, \\ India. \\ *Corresponding author; email: pvsraju@jpr.amity.edu
}

Received: March 4, 2020; accepted: July 31, 2020

\begin{abstract}
RESUMEN
Los fuertes vientos de los tifones producen afloramiento y mezcla del agua de mar y por lo tanto una reducción en la temperatura superficial del mar (TSM). El enfriamiento de la TSM depende de la intensidad y velocidad de desplazamiento del tifón. En este estudio se analiza con ayuda de datos satelitales el enfriamiento de la TSM inducido por el tifón Haikui, el cual produjo dicho enfriamiento en ambos lados de la trayectoria: el enfriamiento del lado derecho se debió al afloramiento y mezcla (los cuales dependen de la intensidad del fenómeno), en tanto que el del lado izquierdo se debió la precipitación. El enfriamiento producido por el tifón Haikui fue de alrededor de $1.9^{\circ} \mathrm{C}$, como resultado tanto de su desplazamiento lento (el cual produjo afloramiento) como de la precipitación. La extensión espacial del enfriamiento de la TSM se incrementó después de que el tifón tocó tierra, sobre todo en las regiones costeras. El enfriamiento de la TSM en el área de estudio tiene una relación inversa con la velocidad de desplazamiento del tifón y con la precipitación. Debido a la intensa precipitación y a las interacciones océano-atmósfera, el enfriamiento de la TSM fue mayor en aguas costeras, las cuales permanecieron frías durante algunos días después de la recalada del tifón.
\end{abstract}

\begin{abstract}
Strong winds in typhoons cause upwelling/mixing of seawater and hence a reduction in sea surface temperature (SST). The SST cooling depends on the intensity and translation speed of the typhoon. In this paper, typhoon Haikui's induced SST cooling was analyzed with satellite-derived data. Haikui produced SST cooling on both sides of the track: the right-side cooling was due to upwelling/mixing (which depend upon the intensity of the typhoon), and rainfall induced SST cooling on the left side. Typhoon Haikui induced SST cooling over the coastal region was found to be about $1.9^{\circ} \mathrm{C}$ due to lower translation speed leading to upwelling, and also due to rainfall. The spatial extent of the cooler SST increased after the typhoon made landfall, especially over coastal regions. SST cooling over the study area has an inverse relation both to the typhoon's translation speed and to rainfall. Due to heavy rainfall and air-sea interaction processes, SST cooling was higher on coastal waters, and cool waters persisted for a few days after the typhoon landfall.
\end{abstract}

Keywords: SST cooling, rainfall, typhoon, latent heat flux, translation speed, coastal waters.

\section{Introduction}

The highest annual intense typhoon frequencies occur in the Northwest Pacific Ocean (NWPO) during the summer (Webster et al., 2005). The variations of the ocean surface and subsurface temperatures during the typhoon season are mainly 
due to the vertical mixing and upwelling processes. Vertical mixing is associated with the upper ocean entrainment process created by wind-induced current velocity shear (Shay et al., 2000; Jaimes and Shay, 2009). Upwelling can be stimulated by cyclonic flow at the ocean surface due to the Ekman pumping (Huang et al., 2009). Temperature cooling on the right side of the typhoon path is mainly attributed to a wind stress vector turned clockwise (Cione and Uhlhorn, 2003). Some typhoons have a coastal influence with strong winds and intense rainfall. Due to strong cyclonic winds, typhoons cause cold wakes at the ocean surface, resulting in lower SST throughout its path (Price et al., 1986; Lin et al., 2003; Lyman et al., 2006; Vechi and Soden, 2007). Chen et al. (2006) found that the translation speed of the typhoon can have significant effects on the asymmetric rainfall distribution and induces a substantial cooling in SST due to entrainment of sub-surface waters. The severity of the typhoon causes a rise in cold wake by ocean mixing and upwelling in relation to wind strength (Emanuel, 1986; Lin et al., 2003; Zhu and Zhang, 2006).

Several studies demonstrate the precipitation mechanisms of typical typhoons (Marks, 1985; Burpee and Black, 1989). Warmer SSTs prior to the occurrence of typhoons provide the required energy for the increase in precipitation rates afterwards. The inner core of typhoons has intensive convective rain, as well as stronger stratiform rain in the rain band than cloud clusters (Chie et al., 2008). Intense rainfall usually occurs in front of the typhoon and the asymmetry in precipitation varies with the severity of the phenomenon, being more asymmetric for weaker typhoons (Lonfat et al., 2004; Kumar et al., 2019). Heavy precipitation occurred in the rear of hurricane Danny (Blackwell, 2000). Heavier precipitation generally occurs far from the center, which is a common feature of weak typhoons.

Ship-borne and float observations are limited to capturing intermittent, violent typhoons over large ocean basins. Therefore, satellite remote sensing observations have the potential to be an efficient and reliable way to provide continuous measurements for quantifying the ocean response to a typhoon. In this study, satellite-derived SST, wind and merged rainfall data were used to investigate typhoon-induced SST variations, in order to emphasize the relationship between typhoon-induced SST cooling and translation speed with rainfall. Rainfall-induced SST cooling over the coastal region is also discussed.

\section{Data and methodology}

The Haikui typhoon information was taken from the JTWC best-track dataset to understand the variations of SST over the NWPO from genesis through landfall. SST data derived from the National Centers for Environmental Information/National Oceanic and Atmospheric Administration Optimum Interpolation SST (NOAA OI SST) was used. SST data was retrieved from the Advanced Very High-Resolution Radiometer (AVHRR) and Advanced Microwave Scanning Radiometer (AMSR) on the NASA Earth Observing System satellite, which included a large-scale adjustment of satellite biases with respect to the in situ data from ships, buoys, and argo floats. The analyses have a spatial grid resolution of $0.25^{\circ}$ and the temporal resolution of 1 day (Reynolds et al., 2007). The Modern Era Retrospective-Analysis for Research and Applications (MERRA) is the National Aeronautics and Space Administration (NASA) atmospheric data reanalysis for the state-of-the art Goddard Earth Observing System Data Assimilation System v. 5.2 (GEOS-5.2) with zonal mean of $2 / 3$ and resolution of $1 / 3^{\circ}$. MERRA focuses on historical analyses of the hydrological cycle covering a wide range of weather and climate time scales (Reichle et al., 2011). The MERRA dataset captures weather and climatological characteristics over the NWPO (Murakami, 2014). Wind, incoming shortwave radiation (insolation), latent heat flux (LHF) and sensible heat flux (SHF) daily averaged data were obtained from MERRA v. 5.2.0. Daily precipitation data was obtained from the Global Precipitation Climatology Project (GPCP) merged precipitation. GPCP was initiated by the World Climate Research Program (WCRP) for a detailed understanding of the spatial and temporal variations of precipitation around the globe. Daily GPCP provides global precipitation products with satellite and gauge information at a $1^{\circ}$ spatial resolution (Huffman et al., 2001). For better understanding the influence of the typhoon and rainfall on SST, we chose the following areas: (1) the study area $\left(22-30^{\circ} \mathrm{N}, 120\right.$ $\left.147^{\circ} \mathrm{E}\right),(2)$ the typhoon genesis area $\left(22.4-23^{\circ} \mathrm{N}\right.$, $\left.141-143^{\circ} \mathrm{E}\right),(3)$ the peak intensity area $\left(27.4-28.8^{\circ} \mathrm{N}\right.$, $122.3-125.5^{\circ} \mathrm{E}$ ), and (4) the coastal area before the typhoon landfall $\left(28-30^{\circ} \mathrm{N}, 121-124^{\circ} \mathrm{E}\right)$. 


\section{Results and discussion}

\subsection{SST variations induced by typhoon Haikui}

Typhoon Haikui originated over the NWPO $\left(22.4^{\circ} \mathrm{N}\right.$, $146.5^{\circ} \mathrm{E}$ ), after typhoons Saola and Damery made landfall on the east coast of China and lower temperatures were experienced over the coastal region. The typhoon Haikui transitioned from tropical depression to tropical storm with pressure of $992 \mathrm{hPa}$. On early hours of August 3, 2012 Haikui moved west following warmer temperatures $\left(>28.3^{\circ} \mathrm{C}\right)$; afterwards, temperature decreased. On August 4, SST dropped $1^{\circ} \mathrm{C}$ around the typhoon center. After de typhoon passed, temperature decreased in the right side of the track. Pressure decreased to $980 \mathrm{hPa}$ on August 5 and the subsequent storm intensified rapidly to a severe tropical storm. Stronger cyclonic typhoon winds increase sea surface divergence and upwelling (Stramma et al., 1986; Monaldo et al., 1997), leading to cooling of the SST. The typhoon trajectory changed to the southwest and the translation speed decelerated. Haikui was upgraded to a class 5 typhoon (JTWC classification) on August 6 , when a pressure of $970 \mathrm{hPa}$ and SST cooling of $0.3{ }^{\circ} \mathrm{C}$ could be observed. A cold wake of SST was observed on August 6; however, on August 7 the cool water disappeared and was replaced by warm waters. The typhoon further intensified and its trajectory changed to the northwest.

The intensity and translation speed of the typhoon influence SST variability (Hormann et al., 2014). While the typhoon is approximating landfall, with strong onshore winds ahead of the eye, the wind shear affects the thermocline, which leads to turbulent entrainment of cold bottom water and its mixing with the surface warm waters turning them cool (Glenn et. al., 2016). The strong onshore winds occurring ahead of the eye in tropical cyclones and the coastal wall set up a downwelling circulation that limits the storm surge and results in significant shear across the thermocline. This shear leads to turbulent entrainment of abundant cold bottom water and its mixing with warmer surface water.

Due to the higher wind intensity and moving speed of Haikui, cooling of the SST $\left(1.7^{\circ} \mathrm{C}\right)$ was observed after the typhoon passed. Haikui intensified further with a decrease in pressure to $965 \mathrm{hPa}$, and became a severe typhoon on August 7 landfalling in Zhejiang province, China, on early hours of August 8. Haikui dissipated slowly after landfall; however, coastal regions experienced strong wind speeds, which resulted in strong upwelling and a decrease in SST to $27.3^{\circ} \mathrm{C}$ on August 9. SST decreased further on August 10 over the coastal waters of Zhejiang and the spatial extent of cooler SST increased. Due to the entrainment of water, the typhoon-induced SST cooling area was positioned to the right of the typhoon track and decreased around $1.9^{\circ} \mathrm{C}$. SST variations, which depend on the translation speed of the typhoon (Lin et al., 2009), can cause rapid changes in circulation attributed to upwelling. Lower translation speed and higher winds entrained subsurface waters and strong upwelling occurred in the right side of the track.

\subsection{Rainfall-induced SST variations during typhoon Haikui}

GPCP merged precipitation data was used to ensure the variations of SST induced by typhoon Haikui rainfall over the study area (Fig. 1). Generally, the most intense precipitation occurs prior to the typhoon and its asymmetry changes with the intensity of the phenomenon. Tahereh and Ismail (2013) found that precipitation rate increases by a large scale after a typhoon. On August 2, typhoon Haikui-generated rainfall occurred on the right side of the track. However, on August 3 rainfall took place in the aftermath of the typhoon. On August 5 typhoon Haikui intensified to category 5 and the left side of its track experienced heavy rainfall. On August 6, rainfall increased, occurring on the left side of the track. However, on August 7 rainfall spread over a large area, with maximum rainfall on the left side of the track. The typhoon made landfall in Zhejiang province on August 8; its intensity decreased and heavy rainfall occurred over the province. Coastal waters also experienced rainfall on August 9. On August 10 rainfall was confined over land and typhoon Haikui subsequently dissipated.

Figure 2 and Table I clearly indicate that translation speed, wind and rainfall induce SST cooling. The process that takes place on the left side of the track is different from the one in the right side. Even though there is a strong cyclonic wind over the ocean surface, upwelling would not occur due to a higher translation speed. Marks (1985) found that precipitation occurs much more often in front of a typhoon than in its rear, with intense precipitation on the right side of the typhoon center; however, it is clear that higher rainfall occurred on the left side 

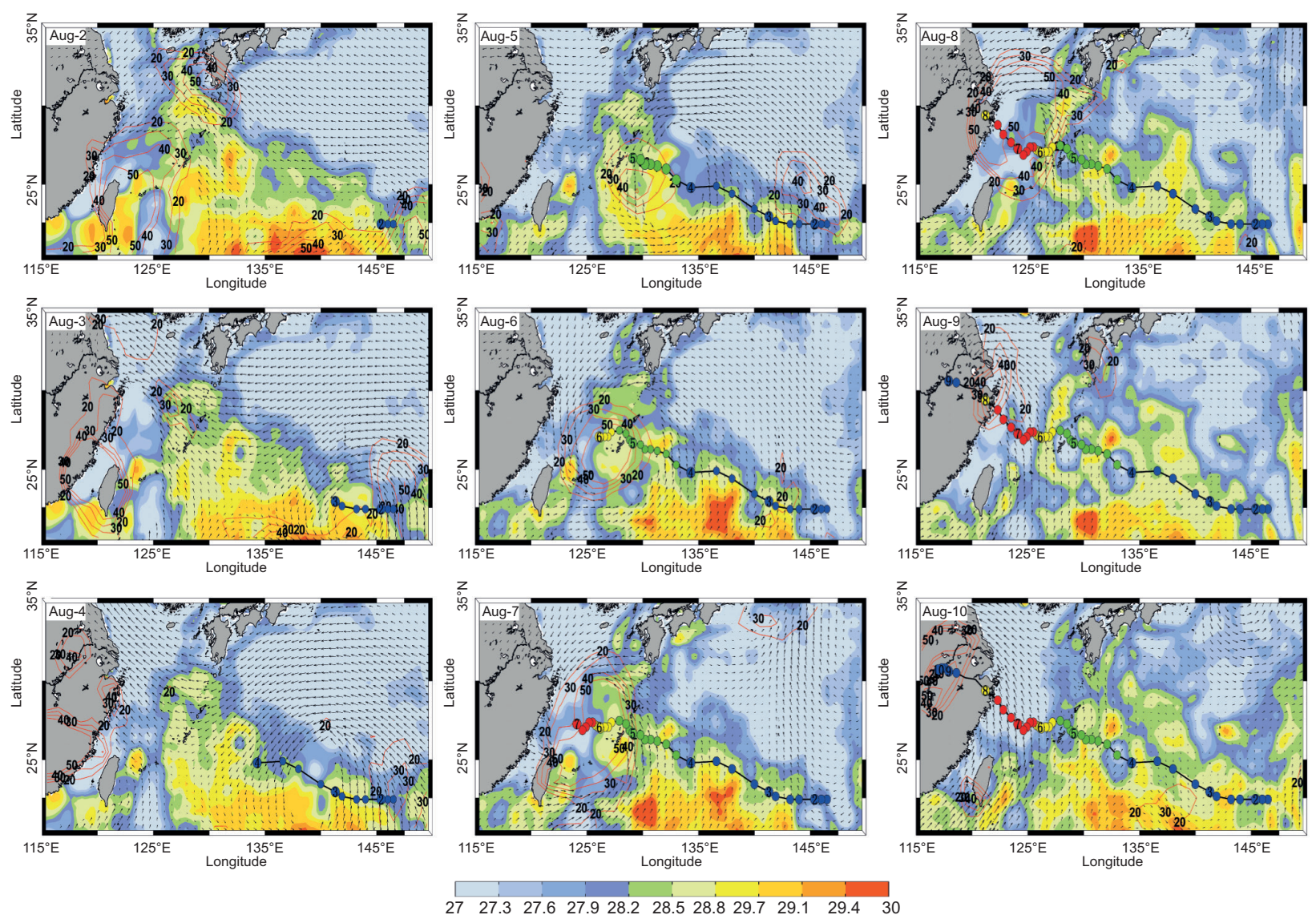

$\begin{array}{lllllllllll}27 & 27.3 & 27.6 & 27.9 & 28.2 & 28.5 & 28.8 & 29.7 & 29.1 & 29.4 & 30\end{array}$

Fig. 1. Variations of SST $\left({ }^{\circ} \mathrm{C}\right.$, shaded), rainfall ( $\mathrm{mm}$, in contour) and wind speed ( $\mathrm{ms}^{-1}$, in vectors) during the typhoon Haikui (August 2-10, 2012).
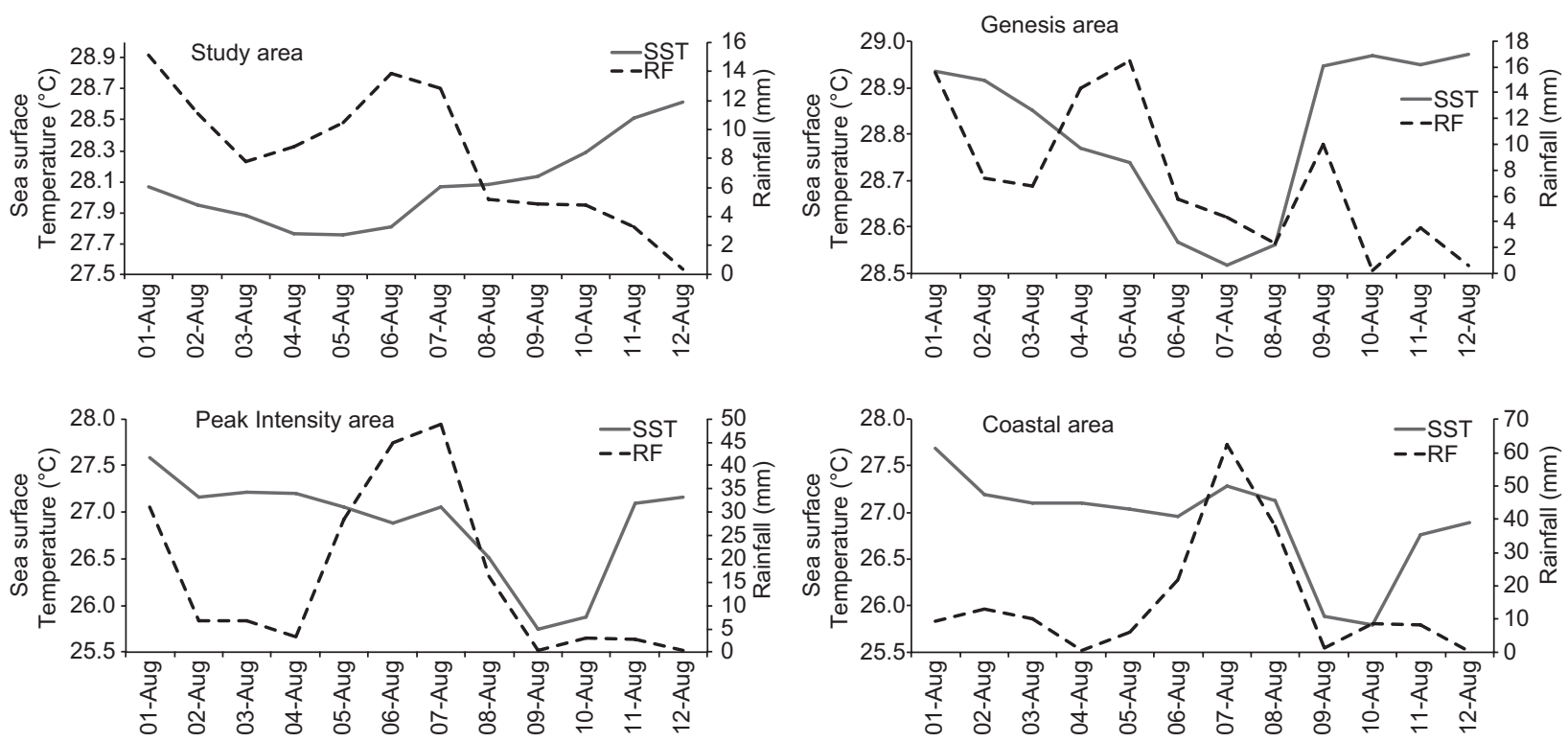

Fig. 2. SST and rainfall variations over the study area $\left(22-30^{\circ} \mathrm{N}, 120-147^{\circ} \mathrm{E}\right)$, the genesis area $\left(22.4-23^{\circ} \mathrm{N}, 141-143^{\circ} \mathrm{E}\right)$, the peak intensity area $\left(27.4-28.8^{\circ} \mathrm{N}, 122.3-125.5^{\circ} \mathrm{E}\right)$ and the coastal area $\left(28-30^{\circ} \mathrm{N}, 121-124^{\circ} \mathrm{E}\right)$ along the typhoon track. 
Table I. Variation of translation speed, pressure, wind speed and SST during typhoon Haikui's study period.

\begin{tabular}{|c|c|c|c|c|c|c|c|c|c|}
\hline \multirow[b]{2}{*}{$\begin{array}{c}\text { Date } \\
\text { (August) }\end{array}$} & \multirow[b]{2}{*}{$\begin{array}{c}\text { Translation } \\
\text { speed } \\
\left(\mathrm{ms}^{-1}\right)\end{array}$} & \multirow[b]{2}{*}{$\begin{array}{l}\text { Change in } \\
\text { pressure* } \\
\quad(\mathrm{mb})\end{array}$} & \multirow[b]{2}{*}{$\begin{array}{c}\text { Peak wind } \\
\text { speed } \\
\left(\mathrm{ms}^{-1}\right)\end{array}$} & \multicolumn{3}{|c|}{ Change in SST $\left({ }^{\circ} \mathrm{C}\right)$} & \multicolumn{3}{|c|}{ Rainfall (mm) } \\
\hline & & & & $\begin{array}{l}\text { Study } \\
\text { area* }\end{array}$ & $\begin{array}{c}\text { Peak } \\
\text { intensity } \\
\text { area* }^{*}\end{array}$ & $\begin{array}{c}\text { Coastal } \\
\text { area* }\end{array}$ & $\begin{array}{c}\text { Study } \\
\text { area }\end{array}$ & $\begin{array}{c}\text { Peak } \\
\text { intensity } \\
\text { area }\end{array}$ & $\begin{array}{c}\text { Coastal } \\
\text { area }\end{array}$ \\
\hline 02 & 3.93 & -2 & - & -0.12 & -0.43 & -0.50 & 11.08 & 6.79 & 13.00 \\
\hline 03 & 6.67 & -10 & 18 & -0.07 & 0.05 & -0.09 & 7.77 & 6.76 & 10.19 \\
\hline 04 & 8.14 & -2 & 18 & -0.11 & -0.01 & -0.01 & 8.81 & 3.27 & 0.39 \\
\hline 05 & 4.96 & -10 & 20.5 & -0.01 & -0.15 & -0.06 & 10.46 & 28.37 & 5.94 \\
\hline 06 & 2.66 & -10 & 28.3 & 0.06 & -0.17 & -0.08 & 13.87 & 44.91 & 21.68 \\
\hline 07 & 2.78 & -5 & 30.9 & 0.25 & 0.17 & 0.33 & 12.82 & 48.86 & 62.46 \\
\hline 08 & 4.61 & 10 & 33.4 & 0.02 & -0.55 & -0.16 & 5.14 & 16.35 & 37.77 \\
\hline 09 & 2.46 & 17 & 23.1 & 0.05 & -0.76 & -1.24 & 4.86 & 0.27 & 1.30 \\
\hline 10 & 1.12 & 4 & 18 & 0.15 & 0.12 & -0.09 & 4.74 & 2.99 & 8.71 \\
\hline 11 & 0.45 & 2 & - & 0.23 & 1.23 & 0.96 & 3.27 & 2.70 & 8.07 \\
\hline 12 & - & - & - & 0.10 & 0.07 & 0.13 & 0.36 & 0.39 & 0.10 \\
\hline
\end{tabular}

*Difference in pressure or SST with respect to previous day.

of typhoon Haikui's track. SST cooling over the left side of the track is mainly due to higher rainfall. Figure 2 clearly indicates that SST cooling happened due to precipitation, but there is a time lag of two days over the coastal area. Heavy rainfall occurred over the coastal regions due to peak intensity of the typhoon. Because of its long duration and lower intensity, typhoon Haikui produced heavy precipitation (Yunhui et al., 2014). This study reveals similar results as those mentioned by Subrahmanyam (2015), who reported that decreased SST on the left side of the track was higher than on the right. In addition, main precipitation areas were found near coastal regions. This may be due to the topography of the area and the convergence of typhoon peripheral wind, as mentioned by Shen et al. (2014), resulting from the strong air-sea interaction, which induced sea water evaporation. Air-sea interactions also play a major role in the SST cooling lag.

\subsection{Variation of translation speed and SST cooling}

Table I shows day to day variations of translation speed, SST, pressure, wind and rainfall during the study period. The relations of translation speed and rainfall with SST are given in Figure 3. Figure 3a shows that translation speed is one of the main sources for upwelling, which reduces SST. A strong correlation coefficient (CC) of -0.78 was found between translation speed and SST. The translation speed of the typhoon has a significant impact on SST (Shay et al., 1998). The very low translation speed (0-1.4 $\left.\mathrm{ms}^{-1}\right)$ of the Kai-Tak typhoon produced a substantial SST cooling of $9{ }^{\circ} \mathrm{C}$ (Lin et al., 2003). Before landfall, Haikui's translation speed reduced to $2.66 \mathrm{~ms}^{-1}$. On August 5-6 there was a drop of $10 \mathrm{hPa}$ and wind speed of $29 \mathrm{~ms}^{-1}$ was recorded. A drop in SST of 0.17 and $0.08{ }^{\circ} \mathrm{C}$ was observed over the peak and coastal areas with rainfall of 44.91 and $21.68 \mathrm{~mm}$, respectively. However, on August 6-7 the translation speed increased concurrently with a pressure drop of $5 \mathrm{hPa}$ and a wind speed of $31 \mathrm{~ms}^{-1}$, but an increase in temperature of 0.17 and $0.33{ }^{\circ} \mathrm{C}$ over the peak and coastal areas, respectively. Precipitation increased over the coastal area $(62.46 \mathrm{~mm})$, and the peak area experienced similar rainfall as the previous day $(44.86 \mathrm{~mm})$. Usually, typhoons can induce SST cooling of more than $2{ }^{\circ} \mathrm{C}$ (Bender et al., 1993; Zhu and Zhang, 2006). Smaller SST variations in the typhoon area may lead to substantial variations in precipitation $(\mathrm{CC}=-0.72)$ (Fig. 3b). The warmer SST prior to a typhoon accumulates the required energy to strengthen the typhoon, which further enhances the evaporation, thereby increasing precipitation during the passage of the typhoon. Warm/cold SSTs can stimulate faster and stronger/slower and weaker winds at sea surface (Lin et al., 2003). 

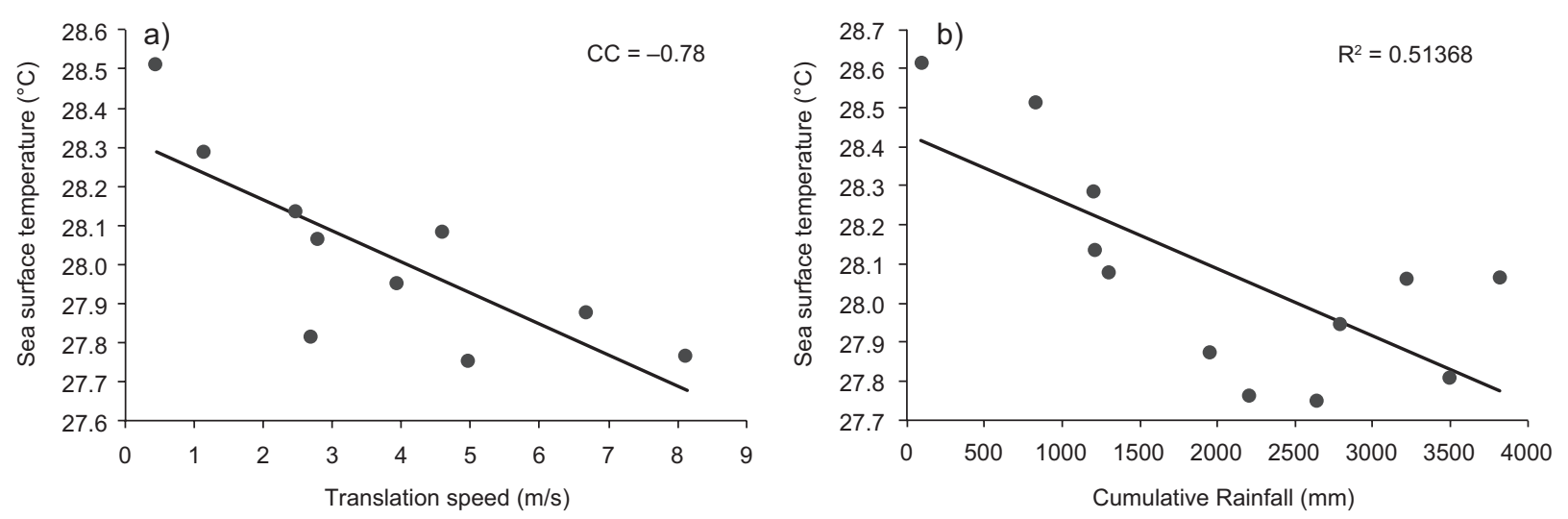

Fig. 3. Scatter plot between (a) translation speed and mean SST, and (b) rainfall and mean SST over the study area. Inverse correlation coefficients (CC) are given in both figures.

\subsection{SST cooling and rainfall variations at different locations over the typhoon track}

SST and rainfall variations in the chosen areas and the influence of the typhoon are presented in Figure 2. Differences in translation speed, intensity (wind speed and pressure), and SST variations in different areas during the typhoon period are given in Table I. Before cyclogenesis (on August 1) mean temperature over the study area was $28.9^{\circ} \mathrm{C}$, which is higher than the previously identified temperature $\left(26.5^{\circ} \mathrm{C}\right)$ for cyclogenesis. The typhoon formation occurred over a narrow time span of $48 \mathrm{~h}$, which is a favorable condition for the formation of typhoons and remained around $28.5^{\circ} \mathrm{C}$ throughout the typhoon period. Overall, temperature decreased by $0.32{ }^{\circ} \mathrm{C}$ over the study area; however, the peak intensity and coastal areas experienced higher cooling than the genesis and study areas. Haikui's peak intensity occurred on August 7 , and the observed SST cooling was $-0.54,-1.08$, and $-1.85^{\circ} \mathrm{C}$ on August 7,8 and 9 , respectively. Due to a higher wind speed and low translation speed (2.46 $\mathrm{ms}^{-1}$ ) of the typhoon over coastal area, the decrease in SST was of $1.9^{\circ} \mathrm{C}$. Deepening and cooling of the mixed layer occurred when translation speed was below $3 \mathrm{~ms}^{-1}$ (Wu and Chen, 2012). SST cooling has an inverse relation with translation speed and precipitation. Typhoon translation speed and precipitation over the peak intensity and coastal areas were more prominent during the typhoon passage and before landfall.

Figure 4 illustrates the variation of parameters over a coastal area during the typhoon period. During the typhoon passage insolation reduces due to an overcast condition. Since peak intensity at a coastal region occurred on August 7, LHF increased to 71 $\mathrm{Wm}^{-2}$ in four days, attaining its peak value (177.6 $\mathrm{Wm}^{-2}$ ), and SHF decreased to $-30.6 \mathrm{Wm}^{-2}$ (heat transfer occurs from atmosphere to ocean surface). Over the coastal region, SST cooling took place slowly before the typhoon landfall, due to higher latent heat from evaporation released to the atmosphere, higher typhoon intensity (which produced strong upwelling), and heavy rainfall $(62.5 \mathrm{~mm})$ leading to cooling of the SST. However, the maximum cooling befell two days later. After the typhoon landfall, heat transfer occurred from the atmosphere to the sea surface (negative SHF), LHF decreased due to a decline in wind speed and SST normalized. Insolation and SHF increases, as well as LHF decrease, led to a gradual increase in SST. This explains that net heat flux has an impact on SST cooling and warming, and also has a good positive relation with SST (CC $=0.74$ ). On the left side of the typhoon after landfall there was a lag in SST cooling and cool weather persisted for a few days due to rainfall and air-sea heat exchange.

\subsection{Causes of the lag in SST cooling over the coas- tal area}

SST cooling and lag in cooling due to rainfall can be explained through air-sea interaction. Figure 4 shows variations in SST, rainfall (at the coastal area and over land), wind, LHF, SHF and insolation over the coastal area. SST deviation and rainfall indicate that, 

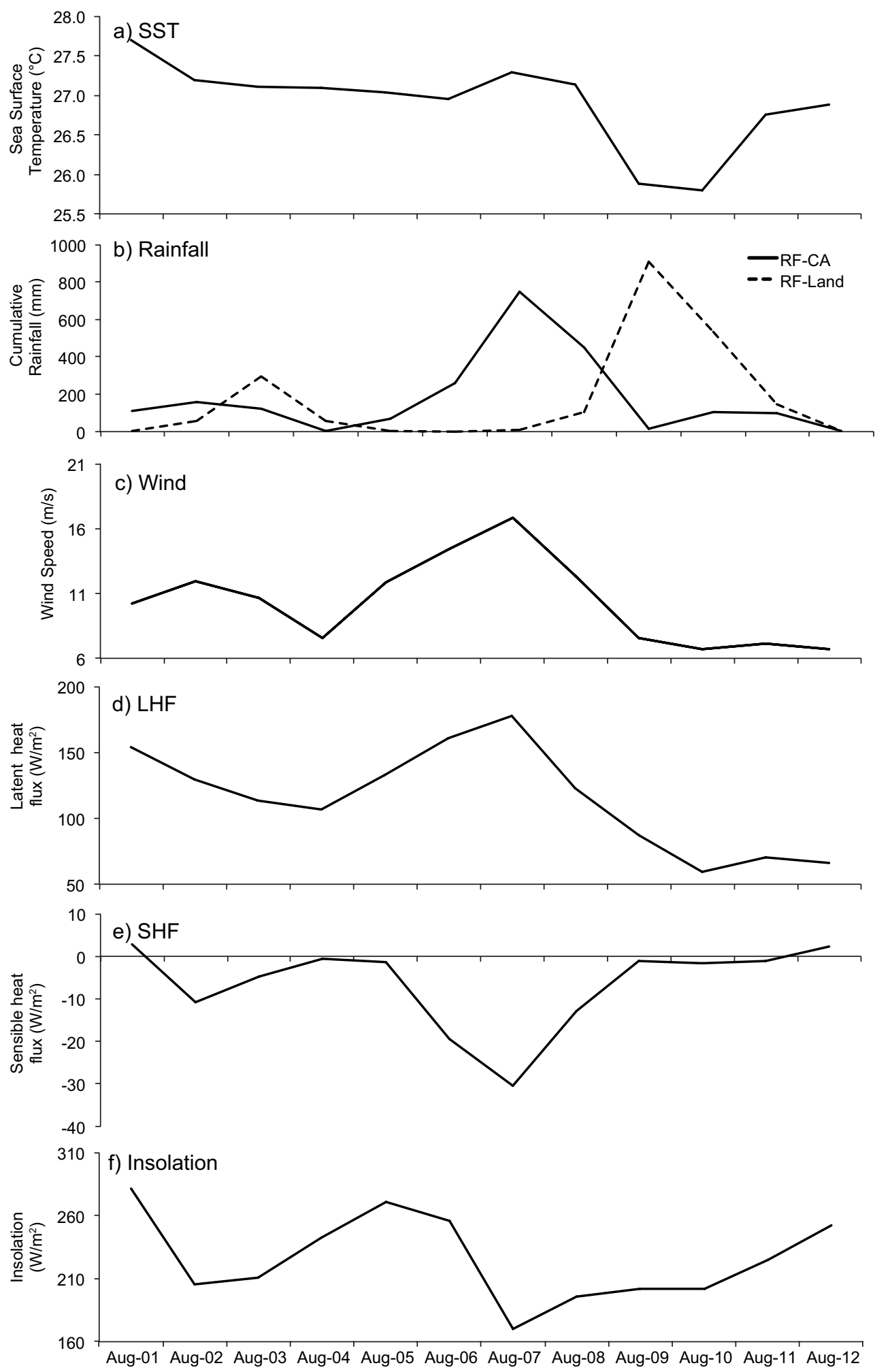

Fig. 4. Variations over the coastal area during typhoon Haikui of (a) SST deviation $\left({ }^{\circ} \mathrm{C}\right)$, (b) rainfall (mm) over the coastal area and land $\left(28-32^{\circ} \mathrm{N}, 115-118^{\circ} \mathrm{E}\right)$, (c) wind speed $\left(\mathrm{ms}^{-1}\right)$, (d) latent heat flux $\left(\mathrm{Wm}^{-2}\right)$, and (e) sensible heat flux and insolation $\left(\mathrm{Wm}^{-2}\right)$. 
SST cooling ensues two days after heavy rainfall over the coastal area due to the typhoon. Figure 4 clearly indicates that when a typhoon hits a coastal region, its intensity increases with higher winds, LHF and rainfall; however, SHF shows negative values.

This process can be explained as follows: SST deviations clearly indicate there is an increase of $0.3^{\circ} \mathrm{C}$; then, SST decreased $0.16{ }^{\circ} \mathrm{C}$ on the next day, and 1.24 and $0.1{ }^{\circ} \mathrm{C}$ on the second and third day, respectively, after the typhoon landfall. Later on, SST slowly increased. The intensity of a typhoon is higher when it is located in the coastal area, since the strong cyclonic winds produce an upwelling leading to SST cooling. After the typhoon landfall, strong wind prevailed for one more day (Table I) (i.e., August 8); then wind decreased gradually leading to mixing over the coastal water. SST cooling occurred even after the landfall of the typhoon. Maximum rainfall was observed at the time of the typhoon landfall over the coastal area, however it was higher after landfall. SST diminished due to runoff from land towards the coastal area. The ocean and air-sea interaction processes over the coastal area explain SST cooling.

The delay in SST cooling due to air-sea interaction can be explained as follows: due to prevailing higher wind speeds, there is an increase in latent heat from evaporation and also in precipitation during the typhoon landfall, leading to SST cooling over the coastal area. Higher LHF indicates that a higher incursion of moisture occurred due to the typhoon. Rainfall continued further at the coastal area even after landfall; however, rainfall increased over land (Fig. 4b). Wind speed decreased over the coastal area after the typhoon landfall. Before landfall, LHF was a dominating over SHF. The higher LHF needs energy from the ocean surface for evaporation, which cools SST and the temperature difference between the atmosphere (air temperature) and ocean (SST) increases. Due to the higher temperature difference between sea and atmosphere, SHF attained its minimum on August $7\left(-30.45 \mathrm{Wm}^{-2}\right)$. An increase in heat exchange with higher SHF was observed after the typhoon landfall. When wind speed decreases after landfall, LHF decreases and SHF slowly increases, i.e., heat exchange moves from the atmosphere to the ocean to attain normal SST. On the other hand, insolation over the coastal area is lower during the typhoon landfall and it further increases slowly, which indicates the rise of atmospheric temperature and increasing SHF.

The typhoon's peak coincided with upwelling due to strong cyclonic winds; however, after landfall, wind speed decreased and the trajectory of the typhoon changed, causing mixing over the coastal waters leading to higher SST cooling. Rainfall continued for a few more days after landfall, therefore mixing of coastal waters, river discharge and (or) coastal runoff were higher due to terrestrial runoff. Due to higher wind speed, LHF attained its maximum, leading to SST cooling. Simultaneously, all these processes led to coastal water stratification, which occurred after two days. SST of coastal waters slowly increased to attain normal temperature by heat transfer from the atmosphere to the ocean; hence, atmosphere and ocean processes led to a lag in cooling.

\section{Conclusion}

SST cooling produced by Haikui was around $1.9^{\circ} \mathrm{C}$ over the coastal area. The typhoon intensified before landfall, producing a strong upwelling in the coastal region leading to SST decrease. The impact of Haikui on SST cooling is also an evidence of its intensity and translation speed. SST cooling can also be observed during the passage of the typhoon. It has a strong inverse correlation with translation speed $(\mathrm{CC}=-0.78)$ and rainfall $(\mathrm{CC}=-0.72)$; nevertheless, more typhoon data is required to endorse this relationship. SST cooling was higher in the left side of the typhoon track than in the right side due to higher rainfall. The occurrence of SST cooling with a lag of two days both in the peak intensity region and in the coastal region (Fig. 2) is mainly due to the air-sea interaction process during the typhoon. Upwelling in the right side of the typhoon track is a dominating factor for SST cooling and depends on translation speed. After the typhoon landfall, heavy rainfall occurred in the left side of the typhoon track; however, there was also heavier rainfall over land during the dissipation of the typhoon. The lower temperature area increased in the left side due to the persistence of rainfall during a few days due to runoff from the coastal area. Due to a decrease in LHF, there is an increase in SHF (exchange is from air to 
sea) and in insolation, leading to normal SST with a lag in time. Further observational and model studies will be pointing towards the dynamical processes of SST cooling due to rainfall.

\section{Acknowledgments}

The authors express their gratitude to NOAA for SST products, MERRA for wind data, and GPCP for daily precipitation data. They also sincerely acknowledge two anonymous reviewers for their valuable comments and suggestions.

\section{References}

Bender MA, Ginis I, Aray K. 1993. Numerical simulations of tropical cyclone-ocean interaction with a high resolution coupled model. Journal of Geophysical Research 98: 23245-23263. https://doi.org/10.1029/ 93JD02370

Blackwell KG. 2000. The evolution of hurricane Danny (1997) at landfall: Doppler observed eyewall replacement, vortex contraction/Intensification, and low-level wind maxima. Monthly Weather Review 128: 40024016. https://doi.org/10.1175/1520-0493

Burpee RW, Black ML. 1989. Temporal and spatial variations of rainfall near the centers of two tropical cyclones. Monthly Weather Review 117: 2204-2218. https://doi.org/10.1175/1520-0493

Chen SS, Knaff JA, Marks FD. 2006. Effects of vertical wind shear and storm motion on tropical cyclone rainfall asymmetries deduced from TRMM. Monthly Weather Review 134: 3190-3208. https://doi. org/10.1175/MWR3245.1

Chie Y, Yukari N, Takayabu. 2008. A statistical study on rain characteristics of tropical cyclones using TRMM satellite data. Monthly Weather Review 136: 38483862. https://doi.org/10.1175/2008MWR2408.1

Cione JJ, Uhlhorn EW. 2003. Sea surface temperature variability in hurricanes: Implications with respect to intensity change. Monthly Weather Review 131: 17831796. https://doi.org/10.1175//2562.1

Emanuel KA. 1986. An air-sea interaction theory for tropical cyclones. Part I: Steady-state maintenance. Journal of Atmospheric Science 43: 585-605. https:// doi.org/10.1175/1520-0469

Glenn SM, Miles TN, Seroka GN, Xu Y, Forney RK, Yu F, Roarty H, Schofield O, Kohut J. 2016. Stratified coastal ocean interactions with tropical cyclones. Nature Communications 7: 1-10. https://doi. org/10.1038/ncomms 10887

Hormann V, Centurioni LR, Rainville L, Lee CM, Braasch LJ. 2014. Response of upper ocean currents to Typhoon Fanapi. Geophysical Research Letters 41: 3995-4003. https://doi.org/10.1002/2014GL060317

Huang PS, Sanford TB, Imberger J. 2009. Heat and turbulent kinetic energy budgets for surface layer cooling induced by the passage of Hurricane Frances (2004). Journal of Geophysical Research 114: C12023. https:// doi.org/10.1029/2009JC005603

Huffman GJ, Adler RF, Morrissey M, Bolvin DT, Curtis S, Joyce R, McGavock B, Susskind J. 2001. Global precipitation at one-degree daily resolution from multi-satellite observations. Journal of Hydrometeorology 2: 36-50. https://doi.org/10.1175/1525-7541

Jaimes B, Shay LK. 2009. Mixed layer cooling in mesoscale oceanic eddies during hurricanes Katrina and Rita. Monthly Weather Review 137: 4188-4207. https://doi.org/10.1175/2009MWR2849.1

Kumar A, Bussireddy NKR, Osuri, KK, Niyogi D. 2020. On the relationship between intensity changes and rainfall distribution in tropical cyclones over the north Indian Ocean. International Journal of Climatology 40: 2015-2025. https://doi.org/10.1002/joc.6315.

Lin I-I, Liu WT, Wu JC, Chiang H, Sui CH. 2003. Satellite observations of modulation of surface winds by typhoon-induced upper ocean cooling. Geophysical Research letters 30: 1131-1134. https://doi. org/10.1029/2002GL015674

Lin I-I, Pun IF, Wu CC. 2009. Upper-ocean thermal structure and the western north Pacific category 5 typhoons. Part II: Dependence on translation speed. Monthly Weather Review 137: 3744-3757. https://doi. org/10.1175/2009MWR2713.1

Lonfat M, Marks FD, Chen SS. 2004. Precipitation distribution in tropical cyclones using the tropical rainfall measuring mission (TRMM) microwave imager: A global perspective. Monthly Weather Review 132: 1645-1660. https://doi.org/10.1175/1520-0493.

Lyman JM, Willis JK, Johnson GC. 2006. Recent cooling in the upper ocean. Geophysical Research Letters 33: L18604. https://10.1029/2006GL027033.

Marks FD. 1985. Evolution of the structure of precipitation in Hurricane Allen (1980). Monthly Weather Review 113: 909-930. https://doi.org/10.1175/1520-0493(198 5)113<0909:EOTSOP>2.0.CO;2 
Monaldo FM, Sikora TD, Babin SM, Sterner RE. 1997. Satellite imagery of sea surface temperature cooling in the wake of Hurricane Edouard (1996). Monthly Weather Review 125: 2716-2721. https:// doi.org/10.1175/1520-0493(1997)125<2716:SIOSS$\mathrm{T}>2.0 . \mathrm{CO} ; 2$

Murakami H. 2014. Tropical cyclones in reanalysis data sets. Geophysical Research Letters 41: 2133-2141. https://doi.org/10.1002/2014GL059519

Price JF, Weller RA, Pinkel R. 1986. Diurnal cycling: Observations and models of the upper ocean response to diurnal heating, cooling, and wind mixing. Journal of Geophysical Research 91: 8411-8427. https://doi. org/10.1029/JC091iC07p08411

Reichle RH, Koster RD, De Lannoy GJM, Forman BA, Liu Q, Mahanama SPP, Toure A. 2011. Assessment and enhancement of MERRA land surface hydrology estimates. Journal of Climate 24: 6322-6338. https:// doi.org/10.1175/JCLI-D-10-05033.1

Reynolds RW, Smith TM, Liu C, Chelton DB, Casey KS, Schlax MG. 2007. Daily high-resolution-blended analyses for sea surface temperature. Journal of Climate 20: 5473-5496. https://doi.org/10.1175/2007JCLI1824.1

Richard AD, McBride JL. 2011. The threshold sea surface temperature condition for tropical cyclogenesis. Journal of Climate 24: 4570-4576. https://doi.org/10.1175/ JCLI-D-10-05006.1

Shay LK, AJ Mariano AJ, Jacob SD, Ryan ED. 1998. Mean and near-inertial ocean current response to hurricane Gilbert. Journal of Physical Oceanography 28: 858889. https://doi.org/10.1175/1520-0485

Shay LK, Goni GJ, Black PG. 2000. Effects of a warm oceanic feature on hurricane Opal. Monthly Weather Review 128: 1366-1383. https://doi.org/10.1175/1520-0493

Shen Y, Zhao P, Pan Y, Yu J. 2014. A high spatiotemporal gauge-satellite merged precipitation analysis over China. Journal of Geophysical Research 119: 3063-3075. https://doi.org/10.1002/2013JD020686.
Stramma L, Cornillon P, Price JF. 1986. Satellite observations of sea surface cooling by hurricanes. Journal of Geophysical Research 9: 5031-5035. https://doi. org/10.1029/JC091iC04p05031

Subrahmanyam MV. 2015. Impact of typhoon on the northwest Pacific sea surface temperature: a case study of Typhoon Kaemi (2006). Natural Hazards 78: 569-582. https://doi.org/10.1007/s11069-015-1733-7

Tahereh H, Ismail WR. 2013. Changes in sea surface temperature and precipitation rate during typhoons in the South China Sea. International Journal of Environmental Science and Development 4: 390-392. https:// doi.org/10.7763/IJESD.2013.V4.378

Vecchi GA, Soden BJ. 2007. Effect of remote sea surface temperature change on potential tropical cyclone intensity. Nature 450: 1066-1070. https://doi.org/10.1038/ nature 06423

Webster PJ, Holland GJ, Curry JA, Chang HR. 2005. Changes in tropical cyclone number, duration, and intensity in a warming environment. Science 309: 1844-1846. https://doi.org/10.1126/science. 1116448

Wu Q, Chen D. 2012. Typhoon-induced variability of the oceanic surface mixed layer observed by Argo floats in the western North Pacific Ocean. Atmosphere-Ocean 50: 4-14. https://doi.org/10.1080/07055900.2012.71 2913

Yunhui C, Ming W, Wu Fan, Tang C, Xuecheng Q. 2014. Analysis of the cause of precipitation difference induced by the typhoons "Jelawat" and "Haikui" with similar tracks. Meteorology and Disaster Reduction Research 37: 18-23.

Zhu T, Zhang DL. 2006. The impact of the storm-induced SST cooling on hurricane intensity. Advances in Atmospheric Sciences 23: 14-22. https://doi.org/10.1007/ s00376-006-0002-9 